Research Paper

\title{
Epidemiological and Clinical Characteristics of the Systemic Lupus Erythematosus at Vinh Phuc Obstetrics and Pediatrics Hospital
}

\author{
Vu Thi Huyen ${ }^{*}$, Nguyen Van Nhien \\ Vinh Phuc Obstetrics and Pediatrics Hospital, 394 Me Linh, \\ Khai Quang, Vinh Yen City, Vinh Phuc, Vietnam \\ Received 14 August 2020 \\ Revised 24 August 2020; Accepted 04 September 2020
}

\begin{abstract}
Purpose: To describe the epidemiological and clinical characteristics of the systemic lupus erythematosus of patients coming to Vinh Phuc Obstetrics and Pediatrics Hospital in 2019.

Methods: A cross-sectional descriptive study was conducted on pediatric patients diagnosed with SLE according to Low Association standards of The United States 1982 (updated 1997) admitted and treated at Vinh Phuc Obstetrics and Pediatrics Hospital from $01 / 2018$ to $12 / 2019$.

Results: Percentage of female was $82.5 \%, 75.4 \%$ live in rural areas. Onset of symptoms $64.9 \%$ were fatigue, $57.9 \%$ were fever. Over $80 \%$ had damage to the skin, mucous membranes and blood. $84.2 \%$ had butterfly erythema, $64.9 \%$ sensitivity to light, $50.9 \%$ mouth ulcers, $42.1 \%$ arthritis, $50.9 \%$ anorexia, $91.2 \%$ hematuria, $87,7 \%$ urinary protein, $61.4 \%$ edema, $50.9 \%$ kidney damage.

Conclusions: Systemic lupus erythematosus usually occurs in females, > 10 years old, the average onset age was 12.7. The disease causes the most damage in the skin, mucous membranes, hematology, musculoskeletal, and kidney. The most common and prominent non-renal lesions were: anemia, erythema papilloma, arthritis, pericardial effusion, pleural effusion. Common kidney damage was edema, microscopic hematuria, proteinuria, leukocytes.
\end{abstract}

Keywords: SLE, children.

\footnotetext{
* Corresponding author.

E-mail address: huyenvu249@gmail.com

https://doi.org/10.25073/jprp.v4i5.228
} 


\title{
Đặc điểm dịch tễ, lâm sàng Lupus ban đỏ hệ thống của bệnh nhi tới khám tại Bệnh viện Sản Nhi Vĩnh Phúc
}

\author{
Vũ Thị Huyền*, Nguyễn Văn Nhiên \\ Bệnh viện Sản Nhi Vĩnh Phúc, 394 Mê Linh, Khai Quang, thành phố Vĩnh Yên, Vĩnh Phúc, Việt Nam \\ Nhận ngày 14 tháng 8 năm 2020 \\ Chỉnh sửa ngày 24 tháng 8 năm 2020; Chấp nhận đăng ngày 04 tháng 9 năm 2020
}

\section{Tóm tắt}

Mục tiêu: Mô tả đặc điểm dịch tễ, lâm sàng lupus ban đỏ hệ thống của bệnh nhi tới khám tại Bệnh viện Sản Nhi Vĩnh Phúc năm 2018 - 2019.

Phương pháp: Mô tả cắt ngang. Bệnh nhi được chẩn đoán SLE theo tiêu chuẩn của Hiệp hội Thấp khớp Hoa Kỳ 1982 (cập nhật 1997) đến khám và điều trị tại Bệnh viện Sản Nhi Vĩnh Phúc từ 01/2018 đến 12/2019.

Kết quả: Tỷ lệ trẻ nữ là $82,5 \%, 75,4 \%$ sống ở nông thôn. Triệu chứng khởi phát $64,9 \%$ là mệt mỏi, $57,9 \%$ là sốt. Trên $80 \%$ có tổn thương ở da, niêm mạc và huyết học. $84,2 \%$ có hồng ban cánh bướm, 64,9\% nhạy cảm với ánh sáng, 50,9\% loét miệng, 42,1\% viêm khớp, $50,9 \%$ chán ăn, $91,2 \%$ tiểu máu, $87,7 \%$ tiểu đạm, $61,4 \%$ phù, $50,9 \%$ thận hư.

Kết luận: Bệnh lupus ban đỏ hệ thống thường xảy ra ở nữ giới, trẻ > 10 tuổi, tuổi khởi phát trung bình là 12,7. Bệnh gây tổn thương nhiều nhất ở da, niêm mạc, huyết học, cơ xương khớp và thận. Các tổn thương ngoài thận phổ biến và nổi bật là: thiếu máu, hồng ban cánh bướm, viêm khớp, tràn dịch màng tim, tràn dịch màng phổi. Tổn thương thận thường gặp là phù, tiểu máu vi thể, tiểu đạm, tiểu bạch cầu.

Từ khóa: Lupus ban đỏ hệ thống, trẻ em.

\section{1. Đặt vấn đề}

Lupus ban đỏ hệ thống (SLE - Systemic lupus erythematosus) là một bệnh ít gặp, đặc biệt là ở trẻ em, tỷ suất hằng năm ở Mỹ khoảng 0,56-0,6/100.000 trẻ [1]. Đây là bệnh tự miễn tổn thương đa cơ quan, trong đó tổn thương thận chiếm tỷ lệ cao khoảng $75 \%$ [2]. Mặc dù nguyên nhân phần lớn không được biết, nhưng sinh lý bệnh được

*Tác giả liên hệ.

Địa chi email: huyenvu249@gmail.com

https://doi.org/10.25073/jprp.v4i5.228 cho là do một số yếu tố. Về mặt lâm sàng, rối loạn này được đặc trưng bởi các giai đoạn thuyên giảm và tái phát và có thể biểu hiện với các triệu chứng cụ thể về cơ quan và cơ quan. Các cân nhắc điều trị chung bao gồm chống nắng, chế độ ăn uống và dinh dưỡng, cai thuốc lá, tập thể dục và chủng ngừa thích hợp, trong khi các phương pháp điều trị cụ thể cho từng cơ quan bao gồm sử dụng thuốc chống viêm steroid và không steroid, chất ức chế miễn dịch và chất sinh học [3]. 
Hiện nay y học chưa tìm ra phương thức chữa trị hoàn toàn căn bệnh này thế nhưng nếu phát hiện sớm và điều trị đúng cách sẽ kiểm soát được diễn tiến của bệnh. Tuy nhiên, ở Việt nam chưa có nhiều công trình nghiên cứu về SLE ở trẻ em. Để nâng cao khả năng khám, phát hiện và điều trị bệnh, chúng tôi tiến hành nghiên cứu nhằm mục tiêu: "Mô tả đặc điểm dịch tễ, lâm sàng lupus ban đỏ hệ thống của bệnh nhi tới khám tại Bệnh viện Sản Nhi Vĩnh Phúc năm 2018-2019".

\section{2. Đối tượng và phương pháp nghiên cứu}

2.1. Đối tuợng, địa điểm và thời gian nghiên cứu

Bệnh nhi được chẩn đoán SLE theo tiêu chuẩn của Hiệp hội Thấp khớp Hoa Kỳ 1982 (cập nhật 1997) đến khám và điều trị tại Bệnh viện Sản Nhi Vĩnh Phúc từ 01/2018 đến 12/2019.

2.1.1. Tiêu chuẩn lựa chọn: lần đầu.

- Bệnh nhi vào viện vì bệnh SLE

- Bệnh nhi chưa từng được điều trị đặc hiệu ở tuyến dưới.

- Gia đình đồng ý tham gia nghiên cứu.

2.1.2. Tiêu chuẩn loại trừ:

- Gia đình không đồng ý tham gia nghiên cứu.

\subsection{Phuong pháp nghiên cứu}

2.2.1. Thiết kế nghiên cứu: Mô tả cắt ngang

2.2.2. Cỡ mẫu và chọn mẫu nghiên cứu $\checkmark$ Chọn mẫu thuận tiện các đối tượng đủ tiêu chuẩn trong khoảng thời gian nghiên cứu.

$\checkmark$ Toàn bộ bệnh nhân Bệnh nhi được chẩn đoán SLE theo tiêu chuẩn của Hiệp hội Thấp khớp Hoa Kỳ 1982 (cập nhật 1997) đến khám và điều trị tại Bệnh viện Sản Nhi Vĩnh Phúc từ 01/2018 đến 12/2019.

$\checkmark$ Thông tin của bệnh nhân được thu thập vào một mẫu bệnh án riêng đã được nghiên cứu từ trước.

Thực tế chúng tôi thu thập được 57 bệnh nhân đủ tiêu chuẩn nghiên cứu.

\subsubsection{Các bước tiến hành}

- Khi phát hiện bệnh nhi bị lupus ban đỏ, bác sĩ tiến hành ghi phiếu điều tra các thông tin đã khám và hỏi bệnh sử.

- Làm các xét nghiệm cơ bản: huyết đồ, VS, điện di đạm, chức năng thận, 10 thông số nước tiểu, XQ phổi thẳng.

- Làm các xét nghiệm đánh giá tổn thương cơ quan: thận, tim, phổi, gan.

- Ghi lại kết quả vào phiếu điều tra và tập hợp lại.

\subsubsection{Thu thập số liệu}

- Thu thập theo mẫu bệnh án nghiên cứu đã được thiết kế từ trước. Quá trình thu thập số liệu do các bác sĩ chuyên khám và phân loại viêm phổi.

- Thu thập số liệu bao gồm: Mỗi bệnh nhi có một bệnh án riêng trong đó ghi chép đầy đủ họ tên, tuổi, giới tính, khu vực nông thôn hay thành thị, mùa vào viện.

\subsubsection{Xử lý số liệu}

Số liệu được nhập và xử lý bằng phần mềm thống kê SPSS 20.0. 


\section{3. Đạo đức trong nghiên cứu}

- Đây là nghiên cứu quan sát không can thiệp, các quy trình chẩn đoán và điều trị viêm phổi theo phác đồ Bệnh viện Sản Nhi Vĩnh Phúc đã được Bộ Y tế phê duyệt

- Các thông tin thu thập được trong điều tra nghiên cứu được giữ bí mật, không được tiết lộ thông tin nghiên cứu cho một cá nhân hay một tổ chức nào khác.

\section{Kết quả nghiên cứu}

Bảng 1. Thông tin chung đối tượng nghiên cứu

\begin{tabular}{|l|l|c|c|}
\hline \multicolumn{2}{|l|}{ Đặc điểm } & Số lượng n=57 & Tỷ lệ \% \\
\hline \multirow{2}{|l|}{$\begin{array}{l}\text { Giới } \\
\text { tính }\end{array}$} & Nam & 10 & 17,5 \\
\cline { 2 - 4 } & Nữ & 47 & 82,5 \\
\hline \multicolumn{2}{|c|}{ Tuổi ( $\bar{X} \pm$ SD) } & \multicolumn{2}{|c|}{$12,7 \pm 3,8$} \\
\hline \multirow{2}{*}{$\begin{array}{l}\text { Noii } \\
\text { sống }\end{array}$} & $\begin{array}{l}\text { Thành } \\
\text { thị }\end{array}$ & 14 & 24,6 \\
\cline { 2 - 4 } & $\begin{array}{l}\text { Nông } \\
\text { thôn }\end{array}$ & 43 & 75,4 \\
\hline
\end{tabular}

Đa số trẻ có giới tính là nữ và sống ở nông thôn, độ tuổi trung bình là $12,7 \pm 3,8$.

Bảng 2. Triệu chứng khởi phát

\begin{tabular}{|l|c|c|}
\hline Triệu chứng khởi phát & $\begin{array}{c}\text { Số lượng } \\
\text { n=57 }\end{array}$ & $\begin{array}{c}\text { Tỷ lệ } \\
\%\end{array}$ \\
\hline Sốt & 33 & 57,9 \\
\hline Mệt mỏi & 37 & 64,9 \\
\hline Sụt cân & 5 & 8,8 \\
\hline
\end{tabular}

Sốt và mệt mỏi là 2 triệu chứng khởi phát phổ biến với xấp xỉ $60 \%$.

Bảng 3. Tổn thương các cơ quan

\begin{tabular}{|l|c|c|}
\hline Cơ quan tổn thương & $\begin{array}{c}\text { Số lượng } \\
\mathrm{n}=57\end{array}$ & Tỷ lệ \% \\
\hline Da niêm mạc & 51 & 89,5 \\
\hline Huyết học & 46 & 80,7 \\
\hline Cơ xương khớp & 37 & 64,9 \\
\hline
\end{tabular}

\begin{tabular}{|l|c|c|}
\hline Thận & 35 & 61,4 \\
\hline Tiêu hóa & 33 & 57,9 \\
\hline Rụng tóc & 32 & 56,1 \\
\hline Thần kinh & 26 & 45,6 \\
\hline Hệ võng nội mô & 21 & 36,8 \\
\hline Phổi & 17 & 29,8 \\
\hline $\begin{array}{l}\text { Viêm mạch máu } \\
\text { ngoại vi }\end{array}$ & 17 & 28,1 \\
\hline Tim & 15 & 26,3 \\
\hline Mắt & 2 & 3,5 \\
\hline
\end{tabular}

Da, niêm mạc, huyết học, cơ xương khớp và thận là những cơ quan có tỷ lệ tổn thương cao nhất.

Bảng 4. Tổn thương ở da, niêm mạc, tóc

\begin{tabular}{|l|c|c|}
\hline $\begin{array}{l}\text { Tổn thương da niêm } \\
\text { mạc }\end{array}$ & $\begin{array}{c}\text { Số lượng } \\
\mathrm{n}=57\end{array}$ & $\begin{array}{c}\text { Tỷ lệ } \\
\%\end{array}$ \\
\hline Hồng ban cánh bướm & 48 & 84,2 \\
\hline Nhạy cảm ánh sáng & 37 & 64,9 \\
\hline Loét miệng & 29 & 50,9 \\
\hline Hồng ban dát sẩn & 17 & 29,8 \\
\hline Hồng ban đĩa & 9 & 15,8 \\
\hline Hồm ban vòm khẩu cái & 8 & 14,0 \\
\hline Tăng sắc tố da & 2 & 3,5 \\
\hline Nốt thấp & 1 & 1,8 \\
\hline Chấm xuất huyết & 1 & 1,8 \\
\hline Rụng tóc & 32 & 56,1 \\
\hline
\end{tabular}

Hồng ban cánh bướm, nhạy cảm ánh sáng, loét miệng là những biểu hiện tổn thương da, niêm mạc phổ biến.

Bảng 5. Tổn thương ở cơ xương khớp

\begin{tabular}{|l|c|c|}
\hline $\begin{array}{l}\text { Tổn thương cơ } \\
\text { xương khớp }\end{array}$ & $\begin{array}{c}\text { Số } \\
\text { lượng }\end{array}$ & $\begin{array}{c}\text { Tỷ lệ } \\
\%\end{array}$ \\
\hline
\end{tabular}




\begin{tabular}{|l|c|c|}
\hline & $\mathrm{n}=57$ & \\
\hline Viêm khớp & 24 & 42,1 \\
\hline Đau khớp & 11 & 19,3 \\
\hline Đau cơ & 6 & 10,5 \\
\hline Viêm cơ & 2 & 3,5 \\
\hline Tràn dịch ổ khớp & 2 & 3,5 \\
\hline
\end{tabular}

Trên 40\% trẻ có viêm khớp, gần $20 \%$ đau khớp và xấp xỉ $10 \%$ đau cơ.

Bảng 6. Tổn thương ở các cơ quan nội trạng trừ thận

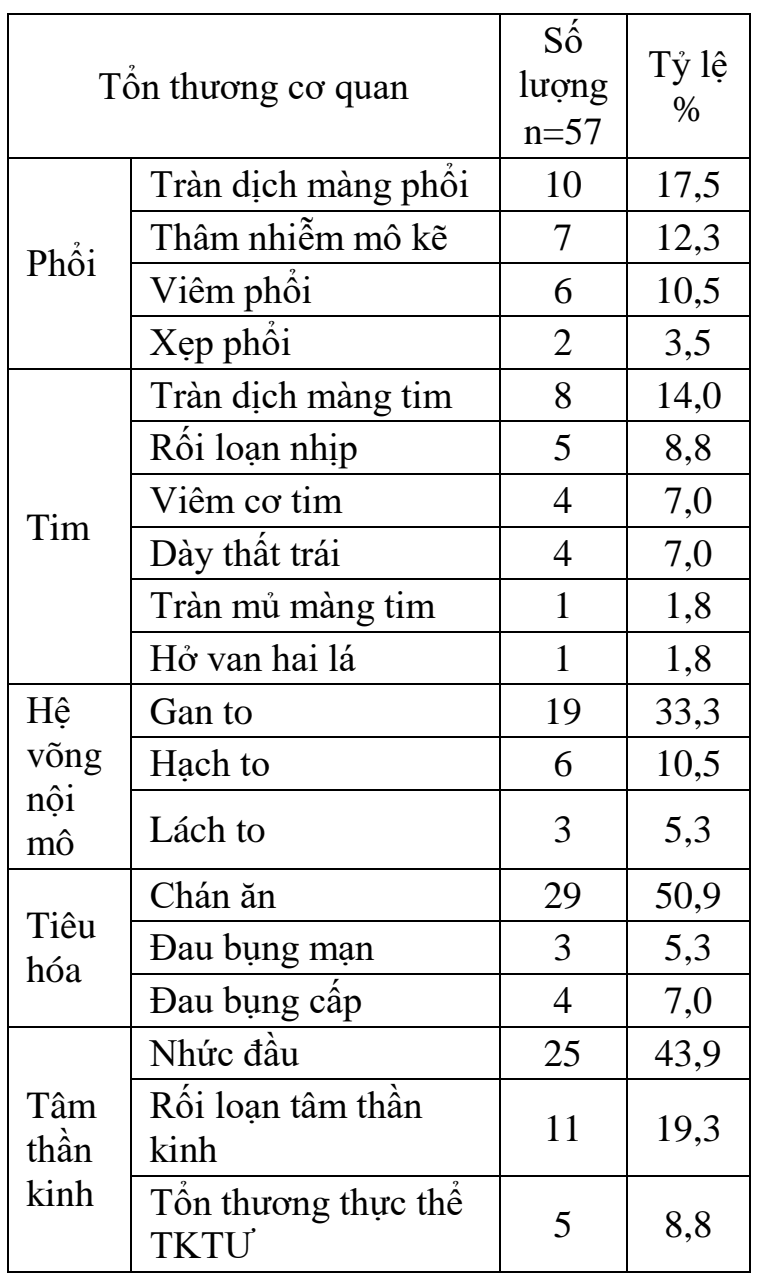

Tràn dịch màng phổi, tràn dịch màng tim, gan to, nhức đầu, chán ăn là những biểu hiện hay gặp ở trẻ.
Bảng 7. Biến đổi về huyết học

\begin{tabular}{|l|c|c|}
\hline Biến đổi huyết học & $\begin{array}{c}\text { Số lượng } \\
\mathrm{n}=57\end{array}$ & Tỷ lệ \% \\
\hline Thiếu máu & 38 & 66,7 \\
\hline Giảm tiểu cầu & 8 & 14,0 \\
\hline Hội chứng Evans & 3 & 5,2 \\
\hline Giảm bạch cầu & 18 & 31,6 \\
\hline Tăng bạch cầu & 8 & 14,0 \\
\hline
\end{tabular}

Khoảng $2 / 3$ số trẻ có biểu hiện thiếu máu, $1 / 3$ có giảm bạch cầu.

Bảng 8. Biểu hiện tổn thương tại thận

\begin{tabular}{|l|c|c|}
\hline \multicolumn{1}{|c|}{ Biểu hiện } & $\begin{array}{c}\text { Số } \\
\text { lượng } \\
\mathrm{n}=57\end{array}$ & $\begin{array}{c}\text { Tỷ lệ } \\
\%\end{array}$ \\
\hline Tiểu máu & 52 & 91,2 \\
\hline Tiểu đạm & 50 & 87,7 \\
\hline Tiểu bạch cầu & 42 & 73,7 \\
\hline Phù & 35 & 61,4 \\
\hline Thận hư & 29 & 50,9 \\
\hline Trụ niệu bất thường & 26 & 45,6 \\
\hline Tăng huyết áp & 20 & 35,1 \\
\hline Giảm độ lọc cầu thận & 17 & 29,8 \\
\hline
\end{tabular}

Tiểu máu, tiểu đạm, tiểu bạch cầu và phù là những biểu hiện hay gặp.

\section{Bàn luận}

Bệnh lupus ban đỏ hệ thống (SLE) là một bệnh tự miễn hệ thống không rõ nguyên nhân, trong đó các phản ứng miễn dịch bình thường chống lại các cơ quan và mô khỏe mạnh. Hệ thống miễn dịch không được kiểm soát tạo ra các kháng thể tấn công da, khớp, thận, tim và não. Một số người bị phát ban nhẹ và viêm khớp, những người khác bị sốt suy nhược, mệt mỏi, đau khớp và các cơ quan nghiêm trọng và/hoặc bệnh đe dọa tính mạng, những thách thức 
của việc chẩn đoán SLE, sự phức tạp của các biểu hiện lâm sàng và các vấn đề điều trị, và tác động của SLE đối với cuộc sống của bệnh nhân. Nghiên cứu này của chúng tôi này chỉ dừng lại đánh giá các đặc điểm lâm sàng và đặc điểm dịch tễ của bệnh nhi đến Bệnh viện Sản Nhi Vĩnh Phúc khám và điều trị trong thời gian nghiên cứu.

Tìm hiểu về đặc điểm dịch tễ học, chúng tôi nhận thấy tuổi khởi phát trung bình là $12,7 \pm 3,8$ tuổi. Kết quả này tương đồng với nhiều nghiên cứu trong và ngoài nước [1-3]. Bệnh đa số khởi phát sau 10 tuổi, chiếm $87,7 \%$. Lehman JA cũng ghi nhận nhóm tuổi $>10$ gấp 3 lần < 10 [4]; Hà Mạnh Tuấn cũng cho ra tỷ lệ là $88,0 \%$ [1]. Giới nữ gặp nhiều hơn nam với tỷ số 4,7 , tương tự trong các y văn thế giới [3]. Theo nghiên cứu của Deborah M. Levy năm 2012 cho thấy: SLE khởi phát thời thơ ấu (SLE) là một bệnh hiếm gặp với tỷ lệ mắc $0,3-0,9$ trên 100.000 trẻ em-tuổi và tỷ lệ hiện mắc là 3,3-8,8 trên 100.000 trẻ. Tần suất SLE cao hơn được báo cáo ở người châu Á, người Mỹ gốc Phi, người gốc Tây Ban Nha và Người Mỹ bản địa. Hầu hết các nghiên cứu báo cáo độ tuổi khởi phát cSLE trung bình từ 11-12 tuổi; bệnh này khá hiếm ở lứa tuổi dưới 5 tuổi.

Triệu chứng khởi phát ở các bệnh nhi lupus, chúng tôi nhận thấy mệt mỏi và sốt là 2 triệu chứng chiếm tỷ lệ cao, xấp xỉ $6 / 10$ trẻ, trong khi đó sụt cân ít gặp hơn với $8,8 \%$. Tuy nhiên sốt và mệt mỏi không phải là một triệu chứng chỉ điểm vì nó thường xuất hiện ở rất nhiều các bệnh lý phổ biến khác và phụ thuộc nhiều vào cảm giác chủ quan của bệnh nhi. Lupus ban đỏ hệ thống là một bệnh tự miễn không rõ nguyên nhân, đặc trưng bởi các đợt cấp và thuyên giảm. Biểu hiện bệnh rất đa dạng, nhưng các triệu chứng phổ biến nhất là mệt mỏi, sốt, sụt cân, phát ban trên da, viêm khớp hoặc đau khớp và thiếu máu. Các phát hiện lâm sàng và đo hiệu giá kháng thể là tiêu chuẩn chẩn đoán phổ biến nhất. Điều trị cá nhân với corticosteroid, thuốc ức chế miễn dịch hoặc thuốc chống sốt rét và theo dõi cẩn thận hoạt động của bệnh là điều cần thiết.

Đặc điểm tổn thương các cơ quan, chúng tôi nhận thấy tất cả các cơ quan từ trong ra ngoài để có thể bị tổn thương. Trong đó, da, niêm mạc và huyết học dễ gặp tổn thương nhất với trên $80 \%$. Thấp hơn là cơ xương khớp, thận với trên $60 \%$. Cơ quan tiêu hóa và tóc trên $50 \%$. Các cơ quan còn lại có tỷ lệ tổn thương thấp hơn. Kết quả của chúng tôi tương đồng với các tác giả trong và ngoài nước $[1,4,5]$. Theo các nghiên cứu của Trung Quốc, của tác giả X Feng nhận xét về các thay đổi đặc điểm lâm sàng và biểu hiện của bệnh lupus thì cho thấy: Bệnh nhân khởi phát vị thành niên có nhiều khả năng không được điều trị trước khi nhập viện $(\mathrm{p}<0,001)$ và có biểu hiện da niêm mạc $(\mathrm{p}<0,001)$, nhưng các triệu chứng cơ xương $(p<0,05)$ và giảm bạch cầu $(\mathrm{p}<0,05)$ ít gặp hơn, trong khi các bệnh đi kèm thì nhiều. cao hơn ở bệnh nhân SLE khởi phát muộn $(\mathrm{p}<0,001)$ [9].

Tổn thương ở da và niêm mạc, đây là nơi có tỷ lệ tổn thương cao và đa dạng. Phổ biến là hồng ban cánh bướm với $84,2 \%$, thấp hơn là nhạy cảm ánh sáng $(64,9 \%)$, loét miệng $(50,9 \%)$, hồng ban dát sần $(29,8 \%)$ và rụng tóc $(56,1 \%)$. Kết quả này cao hơn so với của Cassidy J.T [3], Sultan Bahabri [5] và Shahid Iqbal [6] tuy nhiên, Hà Mạnh Tuấn lại đưa ra nhận xét tương đương [1]. Chúng tôi cho rằng sự khác biệt là do nước ta ở vùng nhiệt đới, tiếp xúc nhiều với tia cực tím do đó khiến tỷ lệ này cao hơn. Ngoài ra hoại tử mạch máu có thể xảy ra ở những bệnh nhân được điều trị bằng corticosteroid và có thể phụ thuộc vào liều lượng thuốc, mặc dù xảy ra ở bệnh nhân SLE nhiều hơn so với các bệnh khác được điều trị tương tự bằng corticosteroid. 
Ngoài ra, tình trạng loãng xương xảy ra thường xuyên, liên quan đến việc sử dụng corticosteroid và tăng nguy cơ gãy xương.

Các biểu hiện ở cơ xương khớp, tỷ lệ viêm khớp trong nghiên cứu của chúng tôi chiếm tỷ lệ cao nhất với $42,1 \%$, ít hơn là đau khớp 19,3\%, đau cơ 10,5\%. Viêm cơ và tràn dịch ổ khớp chỉ chiếm tỷ lệ nhỏ 3,5\%. Tính chất viêm khớp thường nhẹ, 100\% phục hồi hoàn toàn giống như ghi nhận của Sultan Bahabri [5]. Vị trí viêm khớp chúng tôi nhận thấy chủ yếu là khớp lớn hoặc kết hợp khớp nhỏ và lớn. Viêm khớp gối đơn thuần hay kết hợp với các khớp khác chiếm tỷ lệ cao nhất. Còn về đau cơ, vị trí đau chủ yếu là cơ đùi và cơ cẳng chân. Biểu hiện bao gồm đau khớp và viêm khớp, hoại tử vô mạch, gãy xương dễ gãy và đau thứ phát. Viêm khớp xảy ra ở $80 \%$ bệnh nhân mắc SLE, và mặc dù mô tả điển hình là viêm đa khớp gây đau đớn, trên thực tế, một tỷ lệ đáng kể trẻ em bị SLE chỉ cảm thấy đau nhẹ Đau khớp cũng thường xảy ra và có thể là thứ phát sau hội chứng khuếch đại cơn đau xảy ra trong hoặc sau khi bệnh bùng phát với kết quả là ngủ kém và mệt mỏi vào ban ngày, giảm điều hòa tim mạch và đau toàn thân [10].

Tổn thương ở phổi và tổn thương ở tim, tỷ lệ tổn thương là $29,8 \%$ trẻ, $26,3 \%$ trẻ có tổn thương, tỷ lệ cao nhất là tràn dịch màng tim với $14,0 \%$, rối loạn nhịp $8,8 \%$, viêm và dày thất trái chiếm $7,0 \%$.. Kết quả này tương tự Cassidy J.T là $31,0 \%$ [3] và Hà Mạnh Tuấn 30,0\% [1], cao hơn của Glidden RS là 18,0\% [7], Shahid Iqbal là 5\% [6]. Tràn dịch màng phổi trong nghiên cứu của chúng tôi là $17,5 \%$ tuy nhiên thường ở múc độ nhẹ, biến mất sau điều trị và không để lại di chứng. Ngoài ra chúng tôi cũng ghi nhận $12,3 \%$ thâm nhiễm mô kẽ và $10,5 \%$ viêm phổi. Quá trình viêm, viêm thanh mạc là một trong số ít các biểu hiện SLE có liên quan đến protein phản ứng (CRP). Mặc dù tràn dịch màng ngoài tim và màng phổi lớn được nhìn thấy trên phim chụp X-quang hoặc siêu âm tim, nhưng một đợt bùng phát viêm thanh mạc có thể chỉ xuất hiện với cơn đau, dấu hiệu xét nghiệm máu về hoạt động của bệnh và tăng CRP khi đối mặt với những phát hiện tối thiểu trên chụp $\mathrm{X}$-quang. Các biểu hiện tim phổi khác hiếm gặp hơn của SLE bao gồm viêm cơ tim, viêm nội tâm mạc không nhiễm trùng (Libman-Sacks), viêm phổi kẽ, xuất huyết phổi và tăng áp phổi. Đây là những biến chứng thường nghiêm trọng và có thể đe dọa đến tính mạng cần được điều trị tích cực và nhanh chóng

Triệu chứng tâm thần kinh, một điểm đáng lưu ý đó là biểu hiện nhức đầu chiếm 43,9\%. Điều này hợp lý với tỷ lệ trong $\mathrm{y}$ văn cũng như của các tác giả trong và ngoài nước khác. Tuy nhiên, đây cũng là một triệu chứng khó tìm hiểu rõ nguyên nhân. Có 5 trường hợp có tổn thương thực thể hệ thần kinh trương ương, cả 5 trường hợp đều có co giật, 4 trường hợp loạn tri giác và 1 trường hợp liệt nửa người. Tỷ lệ này không có nhiều khác biệt so với Hà Mạnh Tuấn [1] và thấp hơn của Cassidy [3] và Glidden $R S$ [7]. Trong rất nhiều các nghiên cứu có chỉ ra rằng: co giật hiếm khi được nhìn thấy trong cSLE như một sự kiện riêng biệt, nhưng thay vào đó thường được quan sát thấy đồng thời với các hội chứng NPSLE khác. Động kinh cũng có thể xảy ra ở những bệnh nhân bị nhiễm trùng thần kinh trung ương, tăng huyết áp nặng và ở những bệnh nhân có một biến chứng mới được công nhận gần đây được gọi là hội chứng bệnh não có hồi phục sau (PRES). Tình trạng suy giảm khả năng nhận thức có thể được biểu hiện bằng việc giảm sút thành tích học tập và những khó khăn nhỏ khi làm việc với trí nhớ và các nhiệm vụ tập trung. Rối loạn chức năng nhận thức được chẩn đoán bằng xét nghiệm tâm lý thần kinh 
truyền thống và đã được quan sát thấy ở hơn một phần ba bệnh nhân cSLE không có triệu chứng $[9,10]$.

Triệu chứng huyết học, tỷ lệ xảy ra là $80,7 \%$. Thiếu máu là triệu chứng phổ biến với khoảng $2 / 3$ bệnh nhi mắc phải, giảm bạch cầu có tỷ lệ thấp hơn là $31,6 \%$. Kết quả này tương tự Hà Mạnh Tuấn $80 \%$ [1], Shahid Iqbal $85 \%$ [6] và Glidden RS 76\% [7] cao hơn của Sultan Bahabri 66,6\% [5], King KK 46\% [8]. Chúng tôi ghi nhận thiêu máu đa số ở mức độ nhẹ, hồng cầu hầu hết là đẳng sắc đẳng bào, phù hợp với thiếu máu do viêm, tuy nhiên cũng có thiếu máu hồng cầu nhỏ nhược sắc khi bệnh tiến triển nặng và kéo dài. Các nguy cơ chảy máu (trong sọ, trong phúc mạc) tương tự trong giảm tiểu cầu liên quan đến SLE như trong ban xuất huyết giảm tiểu cầu miễn dịch (ITP), do đó, điều trị thường dành cho giảm tiểu cầu có triệu chứng hoặc nghiêm trọng, và cho những bệnh nhân có tiền sử giảm tiểu cầu nặng có biểu hiện giảm cấp tính (tức là bùng phát) số lượng tiểu cầu của họ. Trẻ em và thanh thiếu niên bị ITP mãn tính nên được đánh giá về sự hiện diện của kháng thể kháng nhân vì chúng có nguy cơ cao phát triển SLE.

Tìm hiểu về tổn thương tại thận khá đa dạng, tuy nhiên hay gặp nhất là tiểu máu $91,2 \%$, tiểu đạm $87,7 \%$, tiểu bạch cầu $73,7 \%$, phù $61,4 \%$ và thận hư $50,9 \%$. Kết quả này tương tự với Sultan Bahabri [5]. Lupus ban đỏ hệ thống thường ảnh hưởng nhất đến cầu thận (tức là "viêm thận lupus"), và các kẽ thận hiếm khi liên quan. Ở một bệnh nhân bị suy thận cấp, ban xuất huyết giảm tiểu cầu huyết khối (TTP), bệnh lý vi mô huyết khối nên được xem xét. TTP được thảo luận thêm bên dưới. Vì mức độ nghiêm trọng của viêm thận thường không tương quan với mức độ nghiêm trọng của các dấu hiệu và triệu chứng lâm sàng, nên sinh thiết thận nếu nghi ngờ viêm cầu thận, bao gồm protein niệu nhẹ dai dẳng [10].

\section{Kết luận}

Bệnh lupus ban đỏ hệ thống thường xảy ra ở nữ giới, trẻ $>10$ tuổi, tuổi khởi phát trung bình là 12,7. Bệnh gây tổn thương nhiều nhất ở da, niêm mạc, huyết học, cơ xương khớp và thận. Các tổn thương ngoài thận phổ biến và nổi bật là: thiếu máu, hồng ban cánh bướm, viêm khớp, tràn dịch màng tim, tràn dịch màng phổi. Tổn thương thận thường gặp là phù, tiểu máu vi thể, tiểu đạm, tiểu bạch cầu.

\section{Tài liệu tham khảo}

[1] Tuan HM, Kim HT. Risk factors for hospital infections in the ICU. Medical and Pharmaceutical News 2005;6:139-142 (in Vietnamese)

[2] Tuan NM. Immune hemolysis in children. Residency Graduate Thesis in Paediatrics, University of Medicine and Pharmacy, Ho Chi Minh City 2002. (in Vietnamese)

[3] Cassidy JT. Systemic lupus erythematosus, Juvenile dermatomyositis, Scleroderma and Vasculitis. Kelly's textbook of Rheumatology, $6^{\text {th }}$ ed. W.B Saunders; 2001, p. 1316-1318.

[4] Lehman Thomas JA, Janet A. Mouradian. Systemic lupus erythematosus, Pediatric nephrology, $4^{\text {th }}$ ed, Lippincott Williams \& Wilkins; 1999, p. 793-808.

[5] Bahabri S, Sabban E, Rashed A et al. Juvenile systemic lupus erythematosus in 60 Saudi children. Ann Saudi Med 2019;17(6):612-615. https://doi.org/10.514 4/0256-4947.1997.612

[6] Iqbal S, Sher MR, Good RA et al. Diversity in presenting manifestations of systemic lupus erythematosus in children. J Pediatr 
1999;135(4):500-505. https://doi.org/10.10 16/s0022-3476(99)70174-5.

[7] Glidden RS, Mantzouranis EC, Borel Y. Systemic lupus erythematosus in childhood: clinical manifestations and improved survival in fifty-five patients. Clin Ummunol Immunopathol 1983;29(2):196-210. https://doi.org/10.101 6/0090-1229(83)90024-7

[8] Fortuna G, Brennan MT. Systemic lupus erythematosus: epidemiology, pathophysiology, manifestations, and management. Dent Clin North Am 2013;57(4):631-55. https://doi.org/10.1016/j.cden.2013.06.003.
[9] Feng X, Zou Y, Pan W. Associations of clinical features and prognosis with age at disease onset in patients with systemic lupus erythematosus. Lupus 2014;23(3): 327-340. https://doi.org/10.1177/096120331 3513508 .

[10] Levy DM, Kamphuis. Systemic lupus erythematosus in children and adolescents. Pediatr Clin North Am 2012;59(2): 345364. https://doi.org/10.1016/j.pcl.2012.03.0 07. 